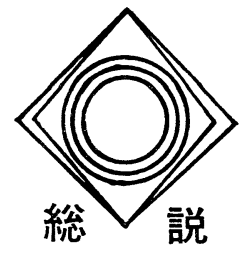

石炭系アスファルテンの化学 (II)

-1981.5 .29 受理一

\section{4. アスファルテンの化学構造}

前節で述べたようにアスファルテンは，その分離に も問題を有しているやっかいな物質であるが，石炭を 液化してオイルを得ようとした場合，2.に述べたよう にその中間生成物としてアスファルテンは存在し，さ らにアスファルテンは石炭液化生成物の物性, 特に粘 度に大きな影響を有するところから 25) 29)，石炭液化 研究においては避けては通られない研究領域となって いる。このような点から, 著者らは石炭の高圧水素化 分解により得られたアスファルテンについて，その化 学構造と反応性について研究を進めてきている。

\section{1 アスファルテンの調製}

アスファルテンは, 石炭化度の異なる5つの北海道 炭から調製された ${ }^{30)}$ 。その高圧水素化分解の反応条件 は反応温度 $400^{\circ} \mathrm{C}$, 水素初圧 $100 \mathrm{~kg} / \mathrm{cm}^{2}$ であり, 触媒と して赤泥一硫黄, 配合油として脱晶アントラセン油を 用いた。分離の方法は，前節で述べた Ruberto流 ${ }^{19}$ に 言兄ば遂次順抽出法 (Forward sequential extraction technique）に分類され，溶媒にはへキサンとベンゼ ンを使用した。図 $10^{300}$ はアスファルテンの収率と原炭 の炭素含量との関係を示したものである。一般に原炭 の炭素含量の増加とともにアスファルテン収率も増加 する傾向が認められ，また反応時間によって20\%から

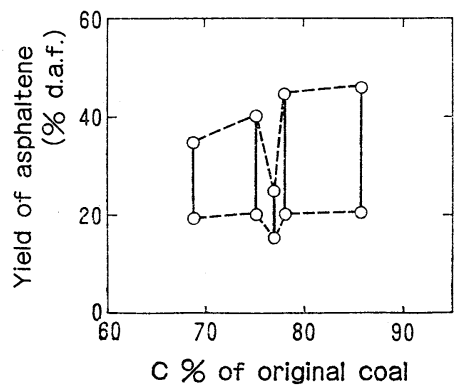

図10 北海道炭の炭素含量とアスファルテン权率 との関係 ${ }^{30)}$

札幌市豊平区月寒東 2 条 17 丁目
北海道工業開発試験所 吉 田 諒 一

$50 \%$ 程度の範囲で変化する。太平洋炭（C=76.9\%） の場合には比較的收率が低く，また反応時間を変化さ せても他の試料炭のような収率の著しい増加は認めら れない。このような太平洋炭の特異な挙動は, 後述す るアスファルテンの平均分子量の測定值についても認 められた。

\section{2 アスファルテンの元素組成}

各試料炭から得たアスファルテンの元素分析值およ び原子比を表 $8^{30}$ と示した。図11 $11^{30}$ は原炭招よび各高 圧水素化分解生成物の元素分析值を $\mathrm{H} / \mathrm{C}-\mathrm{O} / \mathrm{C}$ 線図 に示したものである。アスファルテンは原子比の異な る原炭から調製したにもかかわらず,酸素含量の減少， 水素含量の増加などによって比較的類似した原子比を 有している。図11に示した值は反応時間の短い場合の 值であるが，反応時間を変化させて調製したアスファ ルテンについても同様の傾向が認められた。これらか ら, アスファルテン生成反応は, 元素組成の変化から みると一定の原子比の生成物へと収斂する方向に進行

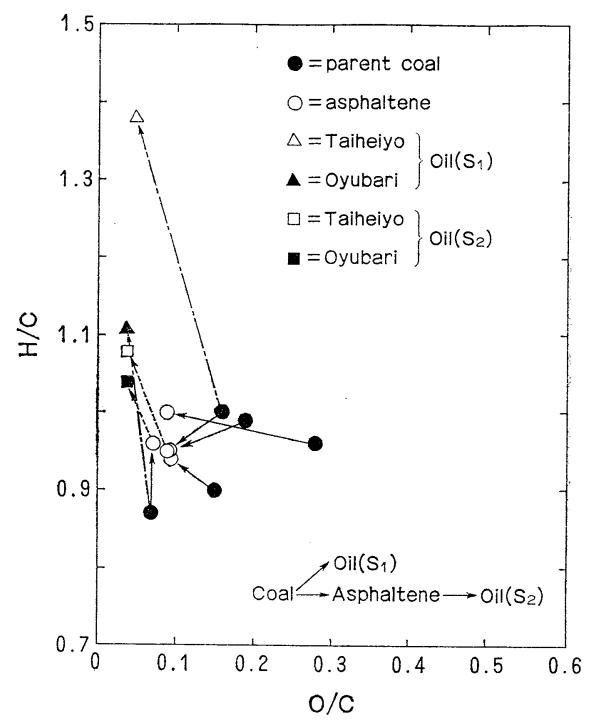

図11 北海道炭およびその各高圧水素化分解生成 物の $\mathrm{H} / \mathrm{C}-\mathrm{O} / \mathrm{C}$ 線図 $^{30)}$ 
表 8 北海道炭およびアスファルテンの元素分析值, 原子比および水酸基性酸素含量とアスファルテン 収率 (反応温度 : $\left.400^{\circ} \mathrm{C}\right)^{30}$ )

\begin{tabular}{|c|c|c|c|c|c|c|c|c|c|}
\hline \multirow[t]{2}{*}{ Sample } & \multirow[t]{2}{*}{$\begin{array}{l}\text { Reaction } \\
\text { time(min.) }\end{array}$} & \multirow[t]{2}{*}{$\begin{array}{l}\text { Yield } \\
\text { (\%d.a.f.) }\end{array}$} & \multicolumn{3}{|c|}{$\begin{array}{l}\text { Ultimate analysis } \\
\text { (\%d.a.f.) }\end{array}$} & \multicolumn{2}{|c|}{ Atomic ratio } & \multicolumn{2}{|c|}{ Hydroxyl-oxygen content } \\
\hline & & & $\mathrm{C}$ & $\mathrm{H}$ & $O($ diff. $)$ & $\mathrm{H} / \mathrm{C}$ & $\mathrm{O} / \mathrm{C}$ & $\overline{\mathrm{O}}$ (\%d.a.f.) & OoH/OTot. $(\%)$ \\
\hline $\begin{array}{l}\text { Soya } \\
\text { coal }\end{array}$ & $\begin{array}{l}\text { original } \\
\text { coal }\end{array}$ & & 68.7 & 5.5 & 25.8 & 0.96 & 0.28 & $10.1^{*}$ & - $44.3^{*}$ \\
\hline asphaltene & $\begin{array}{r}6 \\
22 \\
51 \\
95\end{array}$ & $\begin{array}{l}23.5 \\
28.6 \\
32.7 \\
19.5\end{array}$ & $\begin{array}{l}83.1 \\
84.2 \\
83.4 \\
83.4\end{array}$ & $\begin{array}{l}6.9 \\
7.6 \\
6.6 \\
7.1\end{array}$ & $\begin{array}{r}10.0 \\
8.2 \\
10.0 \\
9.5\end{array}$ & $\begin{array}{l}1.00 \\
1.08 \\
0.95 \\
1.02\end{array}$ & $\begin{array}{l}0.09 \\
0.07 \\
0.09 \\
0.09\end{array}$ & 2.0 & 20.0 \\
\hline $\begin{array}{l}\text { Haboro } \\
\text { coal }\end{array}$ & $\begin{array}{l}\text { original } \\
\text { coal }\end{array}$ & & 75.2 & 6.2 & 18.6 & 0.99 & 0.19 & $8.4^{*}$ & $45.0^{*}$ \\
\hline asphaltene & $\begin{array}{l}31 \\
91\end{array}$ & $\begin{array}{l}28.4 \\
40.2\end{array}$ & $\begin{array}{l}83.0 \\
84.3\end{array}$ & $\begin{array}{l}6.6 \\
6.6\end{array}$ & $\begin{array}{r}10.4 \\
9.1\end{array}$ & $\begin{array}{l}0.95 \\
0.94\end{array}$ & $\begin{array}{l}0.09 \\
0.08\end{array}$ & 3.3 & 31.7 \\
\hline $\begin{array}{l}\text { Taineiyo } \\
\text { coal }\end{array}$ & $\begin{array}{l}\text { original } \\
\text { coal }\end{array}$ & & 76.9 & 6.4 & 16.7 & 1.00 & 0.16 & $7.2^{*}$ & $44.0^{*}$ \\
\hline asphaltene & $\begin{array}{r}9 \\
62 \\
120\end{array}$ & $\begin{array}{l}22.2 \\
20.6 \\
15.2\end{array}$ & $\begin{array}{l}83.4 \\
84.0 \\
84.1\end{array}$ & $\begin{array}{l}6.6 \\
6.7 \\
6.4\end{array}$ & $\begin{array}{r}10.0 \\
9.3 \\
9.5\end{array}$ & $\begin{array}{l}.0 .95 \\
0.96 \\
0.91\end{array}$ & $\begin{array}{l}0.09 \\
0.08 \\
0.08\end{array}$ & 2.3 & 23.0 \\
\hline $\begin{array}{l}\text { Horonai } \\
\text { coal }\end{array}$ & $\begin{array}{l}\text { original } \\
\text { coal }\end{array}$ & & 78.4 & 5.9 & 15.7 & 0.90 & 0.15 & $6.6^{*}$ & $51.4^{*}$ \\
\hline asphaltene & $\begin{array}{r}5 \\
65 \\
114\end{array}$ & $\begin{array}{l}20.3 \\
44.3 \\
34.2\end{array}$ & $\begin{array}{l}83.2 \\
85.2 \\
85.0\end{array}$ & $\begin{array}{l}6.5 \\
6.8 \\
6.5\end{array}$ & $\begin{array}{r}10.3 \\
8.0 \\
8.5\end{array}$ & $\begin{array}{l}0.94 \\
0.96 \\
0.92\end{array}$ & $\begin{array}{l}0.09 \\
0.07 \\
0.08\end{array}$ & 2.5 & 24.2 \\
\hline $\begin{array}{l}\text { Oyubari } \\
\text { coal }\end{array}$ & $\begin{array}{l}\text { original } \\
\text { coal }\end{array}$ & & 85.6 & 6.2 & 8.2 & 0.87 & 0.07 & 1.4 & 17.1 \\
\hline asphaltene & $\begin{array}{r}7 \\
56 \\
117\end{array}$ & $\begin{array}{l}20.6 \\
46.1 \\
42.8\end{array}$ & $\begin{array}{l}85.0 \\
85.8 \\
85.6\end{array}$ & $\begin{array}{l}6.8 \\
6.4 \\
6.4\end{array}$ & $\begin{array}{l}8.2 \\
7.8 \\
8.0\end{array}$ & $\begin{array}{l}0.96 \\
0.90 \\
0.90\end{array}$ & $\begin{array}{l}0.07 \\
0.07 \\
0.07\end{array}$ & 1.1 & 13.4 \\
\hline
\end{tabular}

するものと考えられる。Baltisberger ら ${ }^{32}$ も亜炭およ び歴青炭から調製したSRL および SRC が同様の傾 向を示すことを報告している。

アスファルテン中の炭素, 水素の定量には燃焼法に 基づくセミミクロ分析（試料量 20〜 40mg），窒素の定 量には燃焼法に基づくセミミク口分析(試料炭 $30 \mathrm{mg}$ ), 酸素の定量には熱分解法に基づくミクロ分析（試料量 1〜3mg）が通常用いられるが，高速中性子放射化分 析法 ${ }^{33}$ による酸素の定量なども検討されている。

4.3 アスファルテン中の官能基

Bodzek ら ${ }^{34)}$ は, 電界電離型 (Field-ionization) マ ススペクトロメトリーを用いてアスファルテン中のへ テロ原子の存在形態について検討した。その結果，ア スファルテンの塩基性フラクション $(\mathrm{BA})^{35}$ 中 中窒素 はフェニルピリジン，キノリン，ジハイドロキノリ ン, フェニルキノリン, アクリジン，テトラハイドロ アクリジン，ベンゾアクリジンおよびジベンゾアクリ ジンのようなピリジン誘導体並びにアミン類として存 在し，アスファルテンの酸性/中性フラクション（A $\mathrm{A})^{35)}$ 中にはピロール環として存在する。酸素はBA中 ルはフラン環あるいはェーテル結合として存在し，A A中にはフェノール性水酸基として存在するが，八イ ドロオキシアセトフエノン，ハイドロオキシベンゾフ

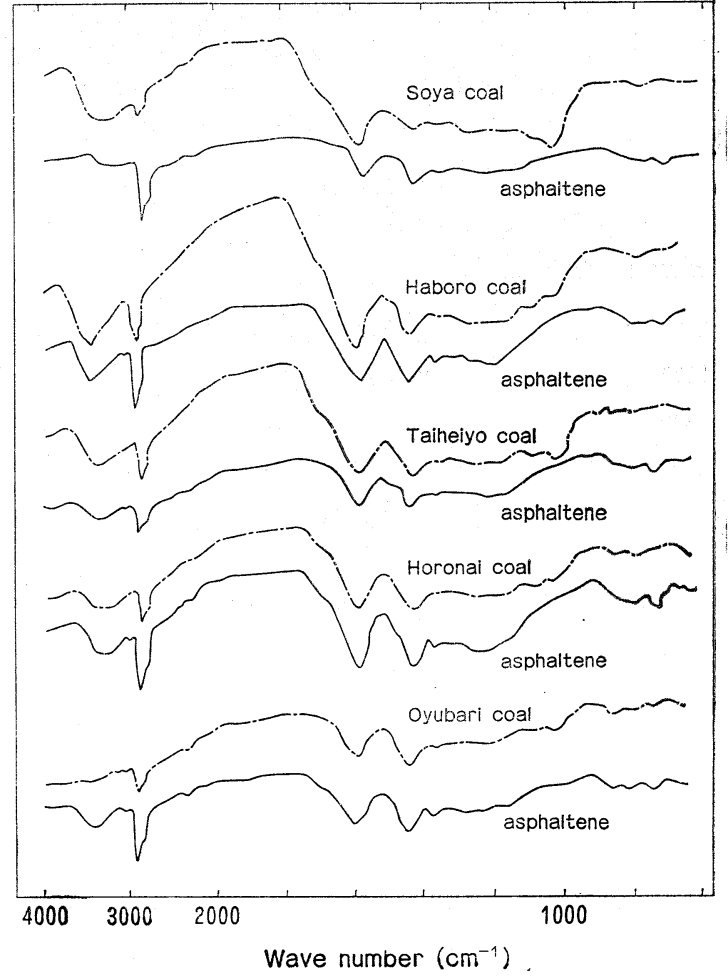

図12 北海道炭およびアスファルテンの IR スペクト ル 


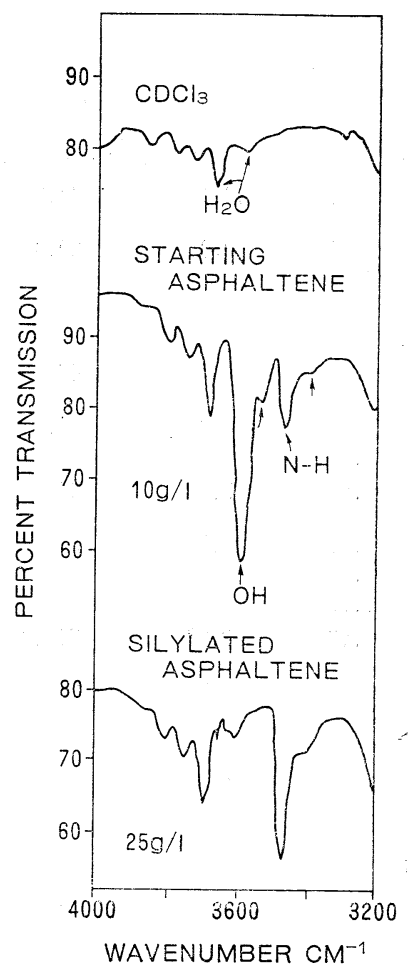

図13 Synthoil アスファルテンおよびシリル化 した Synthoil アスファルテンの OH およ び NH 領域の IR スペクトル（溶媒： $\left.\mathrm{CDCl}_{3}\right)^{38)}$

表 9 アスファルテンの○Hおよび $\mathrm{NH}$ 領域におけ る IR バンドの帰尿 (溶媒 : $\left.\mathrm{CDCl}_{3}\right)^{38}$

wave number, $\mathrm{cm}^{-1}$ assignment

$\begin{array}{ll}3690 & \text { water } \\ 3600 & \text { water } \\ 3600 & \text { free phenolic } \mathrm{OH} \\ 3540 & \text { associated phenolic } \mathrm{OH} \text { or } \\ & \mathrm{OH} \text { independent of phenoli } \\ & \mathrm{OH} \\ 3470 & \text { pyrrolic NH } \\ 3400 & \text { other } \mathrm{NH}, \text { possibly amires } \\ & \text { and/or amides }\end{array}$

3400-3200 (broad) H-bonded acidic components

ラン，ハイドロオキシインダノフランあるいはジハイ ドロオキシアントラセンなどのように 1 分子中に酸素 原子 2 個を有する化合物も見い出された。また BA 中

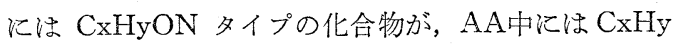
$\mathrm{ON}_{2}$ 叔よび $\mathrm{CxHyO}_{2} \mathrm{~N}$ タイプのオキサザ（oxaza） 化合物も見い出された。硫黄化合物はBA 中には存在

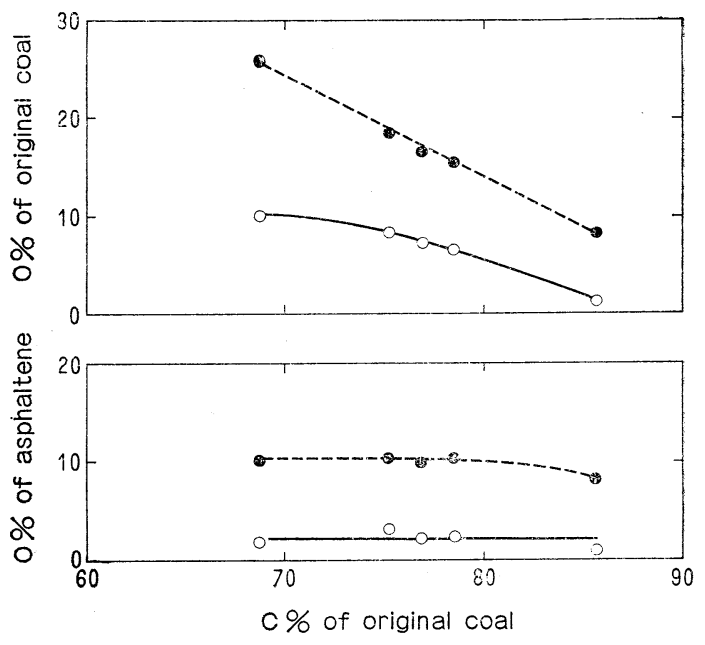

図14 北海道炭の炭素含量と原炭およびアスファルテ ン中の全酸素含量および水酸基性酸素含量との 関係 ${ }^{30}$

しないが，AA 中にはチオフェン誘導体として存在す る。IR スペクトルからも含酸素特よび含穻素官能基 に関する知見が得られる。図 $12^{36)}$ は北海道孷 5 種の原 炭和よびアスファルテンについて $\mathrm{KBr}$ 錠剤法で測定 した IR スペクトルを示したものである。 $3300 \mathrm{~cm}^{-1} に$ は水酸基 $\mathrm{OH}$ 伸縮浱動，1700 $1720 \mathrm{~cm}^{-1}$ にはカルボニ ル基，1030および $1250 \mathrm{~cm}^{-1} に は ~ C-O$ 和よびC-O-C, および $1600 \mathrm{~cm}^{-1}$ 近辺にはその一部は水素結合した C =O に帰因する吸収带が観察される。Brown ら ${ }^{37)}$ 小 よび Schwager ら ${ }^{38}$ は溶液法で Synthoil アスファル テンの IR スペクトルを測定し，3200～3700 $\mathrm{cm}^{-1}$ に掠 けるー $\mathrm{OH}$ およびーNH に基づく種々の吸収帯（図

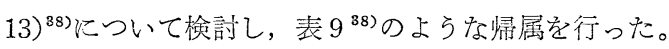
アスファルテンの水酸基の定量法として, トリメチル シリルエーテル形成と重量分析との併用法 ${ }^{39}$, また最 近になってトリメチルシリルエーテル形成と原子吸光 分析との併用法 ${ }^{40)}$ 和よびトリメチルシリルェーテル形 成亡 NMR 分析との併用法 ${ }^{41142)}$ が開発されているが, 図 $14^{30}$ には無水酶酸一ピリジン法 ${ }^{31}$ により測定した北 海道叔预よびアスファルテンの水酸基含量を示した。 図14よりアスファルテンでは全酸素含量, 水酸基酸素 含量が原炭の值よりむ少なく，原炭の場合に比べて炭 種による相違が非常に少ないことがわかる。このこと は4.2 の元素組成の結果と同滕にアスファルテン生成 反応が類似した組成の生成物へと収斂する方向に進行 することを示するのと考光られる。Husack ら ${ }^{43}$ はア ルカリ水溶液执よび Claisen アルカリ抽出安行い, ア 
表 10 アスファルテンの含酸素官能基分布 ${ }^{44)}$

Sample* Ultimate analysis(\% d.a.f.)

Distribution of functional oxygen containing groups(\% d.a.f.)

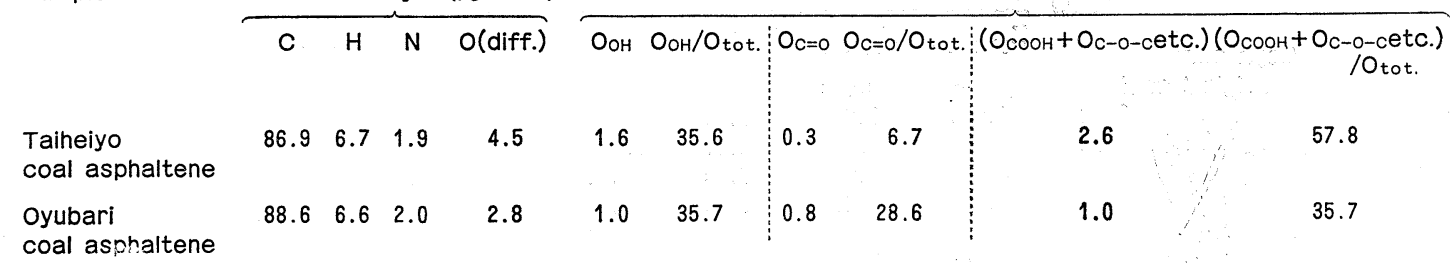

* prepared under the reaction conditions of $400^{\circ} \mathrm{C}, 194 \sim 259 \mathrm{~kg} / \mathrm{cm}^{2}$ and $123 \sim 124 \mathrm{~min}$. by using a rotating-type autoclave $(12-$ litre $)$

スファルテン中にはアルキル/フェニルフェノール 類 と芳香族縮合環構造を有するフェノール類の 2 つのタ イプが存在することを示した。ここで, Claisen アルカ リとは, $\mathrm{KOH} 300 \mathrm{~g}$ を $250 \mathrm{~m} \ell$ の水に溶解し, 全容積 が $1000 \mathrm{~m}$ になるようにメタノールを加えたものであ る。表1044には表 8 とは異なる条件で調製されたアス ファルテンの含酸素官能基分布を示した。カルボニル 基 $(\mathrm{C}=\mathrm{O})$ はオキシム法 ${ }^{31}$ により定量した。 Ruberto ら ${ }^{45)}$ は, 酢酸カルシウムを用いてイオン交換法により アスファルテン中のカルボキシル基 (- $\mathrm{COOH}$ )を測 定したが，アスファルテンからは検出されていない。

IR スペクトルは炭化水素官能基に関する知見をも 与える。図12に示したように，3030 $\mathrm{cm}^{-1}$ には芳香族 $\mathrm{CH}$ 伸縮振動, $2920 \mathrm{~cm}^{-1}$ には脂肪族 $\mathrm{CH}$ 伸縮振動, $1450 \mathrm{~cm}^{-1}$ の $\mathrm{CH}_{2}$ および $\mathrm{CH}_{3}$ 変角振動, $1370 \mathrm{~cm}^{-1}$ に は $\mathrm{CH}_{3}$ 変角振動, 並びに 870,820 おび $750 \mathrm{~cm}^{-1}$ には 芳香族 $\mathrm{CH}$ 面外振動による四收营が認められる。ア スファルテンと原炭とはほぼ同様の IR スペクトルを 与えるが,アスファルテンと原崖との相違は, $3030 \mathrm{~cm}^{-1}$ の芳香族 $\mathrm{CH}$ 伸縮振動に帰因する吸収带に特いて認 められる。3030 $\mathrm{cm}^{-1}$ の吸収带は, 原炭では幌内炭 $(\mathrm{C}=78.4 \%)$ より石炭化度の低い石炭では認められ ず, 大夕張炭 $(\mathrm{C}=85.6 \%)$ で明膫となっているが, ア スファルテンでは出発物質の原炭の石炭化度に関係な くすべてのアスファルテンに現われている。さらにメ チル基については, Field-ionization マススペクトロ メトリーによる研究からアスファルテンの塩基性フラ クション $(\mathrm{BA})$ では平均 1 分子当たり 2 個のメチル基, 酸性/中性フラクション (ANA) では平均 1 分子当た り2.5個のメチル基を有することが明らかになった

4.4 アスファルテンの各種結合形態水素含有率

アスファルテン中の水素はその結合形態によって分 類することができ，またこれらの分布はIR スペクト
ル分析执よび高分解能 NMRスペクトル分析によって 求めることができる。

IR スペクトル分析では, 図12に示されているよう に $3030 \mathrm{~cm}^{-1}$ の芳香族 $\mathrm{CH}$ 伸縮振動和よび $2920 \mathrm{~cm}^{-1}$ の 脂肪族 $\mathrm{CH}$ 伸縮振動の吸光度, Dar および Dal, を 用いて芳香族水素 $\mathrm{Har}$ と脂肪族水素 $\mathrm{Hal}$ との比を求 めることができる。但し，この場合，次式で示される ように

$$
\frac{\mathrm{Dar}}{\mathrm{Dal}}=\frac{\varepsilon_{\mathrm{ar}}}{\varepsilon_{\mathrm{a} 1}} \cdot \frac{\mathrm{Har}}{\mathrm{Hal}}
$$

分子吸光係数の比 $\varepsilon_{\mathrm{ar}} / \varepsilon_{\mathrm{al}}$ を予め求めて打く必要があ る。北海道炭アスファルテンについて, Dar/Dal を IR スペクトル分析から, $\mathrm{Har} / \mathrm{Hal}$ を高分解能 NMR スペクトル分析から求め， $\varepsilon_{\mathrm{ar}} / \varepsilon_{\mathrm{al}}$ を概算した結果を 表11 ${ }^{30)}$ に示した。 $\mathrm{KBr}$ 錠剂法でIRスペクトルを測定 した場合の北海道㟶アスファルテンの分子吸光係数の 比 $\varepsilon_{\mathrm{ar}} / \varepsilon_{\mathrm{a} 1}$ は $0.02 \sim 0.24$ であり, Brown ${ }^{46)}$ が石炭に ついて提案した值 0.5 特よび Francis ${ }^{47)}$ の值 0.44 よ りも小さい。この原因については，すでに検討がなさ れているが36), さらに詳細な検討が必要であろら。

図 $15^{36)}$ はアスファルテンを重水素ピリジンを溶某と して用い測定した高分解能 NMRスペクトルを示した るのである。図中には重水素ピリジン中に存在する不 純物 $\mathrm{C}_{5} \mathrm{H}_{5} \mathrm{~N}$ の鋭いシグナルも現われている。6.40〜 9.00p.p.m. のブロードなピークは芳香族水素 $(\mathrm{Ha})$ であり芳香族核中の水素に相当する。2.00〜4.00p.p. m. のシグナルは劳香族環に結合する脂肪族炭化水素 置換基の $\alpha$ 位炭素につく水素( $\mathrm{H} \alpha)$ であり, 0.50 2.00 p. p. m. のシグナルは芳香族環に結合する脂肪族炭化 水素置換基の $\beta$ 位以上の各炭素につく水素 (Ho)であ る。このような高分解能 NMR スペクトルより求めた 各種結合形態水素含有率を表 11 和よび図 $16^{30}$ ) に示し た。各種結合形態水素含有率は炭種, アスファルテン 
表 11 高分解能 NMR および IR 分析による北海道炭アスファルテンの水素分布 ${ }^{36)}$

\begin{tabular}{|c|c|c|c|c|c|c|c|c|c|}
\hline \multirow{2}{*}{$\begin{array}{l}\text { Sample } \\
\text { Soya coal }\end{array}$} & \multirow{2}{*}{$(\min )}$. & \multicolumn{3}{|c|}{ Infra-red } & Nuclear & \multicolumn{3}{|c|}{ Magnetic Resonance } & \multirow{2}{*}{$\frac{\varepsilon_{\mathrm{ar}}}{\varepsilon_{\mathrm{al}}}$} \\
\hline & & $\mathbf{K}_{3030 \mathrm{~cm}^{-1}}$ & $\mathrm{~K}_{2920 \mathrm{~cm}^{-1}}$ & Dar/Dal & $\mathrm{Ha}$ & $\mathrm{H} \alpha$ & Ho & $\mathrm{Har} / \mathrm{Hal}$ & \\
\hline \multirow[t]{2}{*}{ Original coal } & & - & 0.083 & & & & & & \\
\hline & 6 & 0.005 & 0.326 & 0.01 & 0.246 & 0.253 & 0.501 & 0.33 & 0.03 \\
\hline \multirow{3}{*}{ Asphaltene } & 22 & 0.003 & 0.294 & 0.01 & 0.299 & 0.239 & 0.462 & 0.43 & 0.02 \\
\hline & 51 & 0.009 & 0.180 & 0.05 & 0.342 & 0.326 & 0.332 & 0.52 & 0.10 \\
\hline & 95 & 0.005 & 0.238 & 0.02 & 0.239 & 0.288 & 0.472 & 0.31 & 0.06 \\
\hline \multicolumn{5}{|l|}{ Haboro coal } & & & & & \\
\hline \multirow{2}{*}{ Asphaltene \{} & 31 & 0.013 & 0.222 & 0.06 & 0.290 & 0.303 & 0.407 & 0.41 & 0.15 \\
\hline & 91 & 0.021 & 0.204 & 0.10 & 0.413 & 0.289 & 0.298 & 0.70 & 0.14 \\
\hline \multicolumn{10}{|l|}{ Taiheiyo coal } \\
\hline Original coal & 9 & $0 . \overline{007}$ & $\begin{array}{l}0.215 \\
0.134\end{array}$ & 0.05 & 0.392 & 0.304 & 0.304 & 0.64 & 0.08 \\
\hline \multirow[t]{2}{*}{ Asphaltene } & 62 & 0.008 & 0.181 & 0.04 & 0.372 & 0.296 & 0.332 & 0.59 & 0.07 \\
\hline & 120 & 0.010 & 0.177 & 0.05 & 0.376 & 0.312 & 0.312 & 0.60 & 0.08 \\
\hline \multicolumn{10}{|c|}{ Hor onai coal } \\
\hline \multirow[t]{2}{*}{ Original coal } & & - & 0.229 & & & & & & \\
\hline & 5 & 0.012 & 0.271 & 0.05 & 0.293 & 0.333 & 0.373 & 0.42 & 0.12 \\
\hline \multirow[t]{2}{*}{ Asphaltene } & 65 & 0.010 & 0.206 & 0.05 & 0.312 & 0.298 & 0.391 & 0.45 & 0.11 \\
\hline & 114 & 0.008 & 0.192 & 0.04 & 0.323 & 0.333 & 0.344 & 0.48 & 0.08 \\
\hline \multicolumn{10}{|l|}{ Oyubari coal } \\
\hline \multirow[t]{2}{*}{ Original coal } & & 0.010 & 0.208 & 0.05 & & & & & \\
\hline & 7 & 0.008 & 0.265 & 0.03 & 0.289 & 0.307 & 0.404 & 0.4 & 0.07 \\
\hline \multirow[t]{2}{*}{ Asphaltene } & 56 & 0.011 & 0.226 & 0.05 & 0.355 & 0.308 & 0.337 & 0.55 & 0.09 \\
\hline & 117 & 0.025 & 0.207 & 0.12 & 0.339 & 0.324 & 0.337 & 0.51 & 0.24 \\
\hline
\end{tabular}

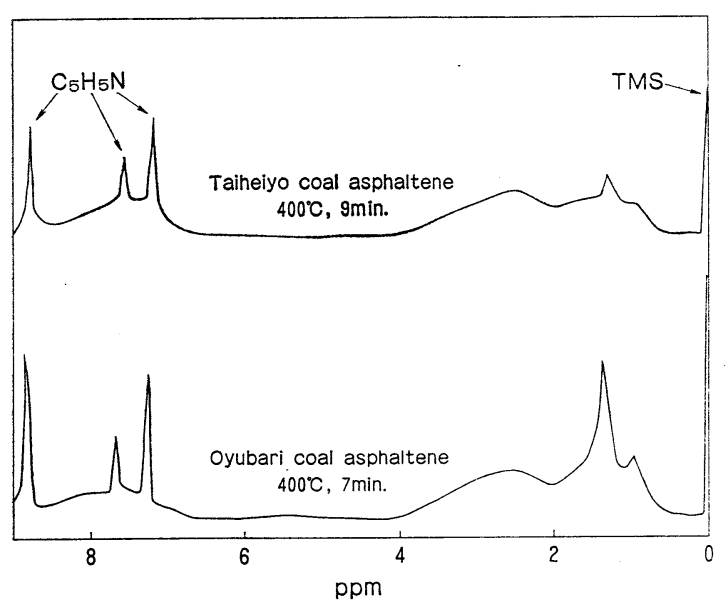

図15 石炭系アスファルテンの高分解能 NMRスペク トル ${ }^{38)}$

の生成条件によって幅広く分布しているが，全般的に みると， $\mathrm{Ha}$ 和よび $\mathrm{H} \alpha$ はアスファルテンおよび原炭 の炭素含量の増加とともに増加の傾向を示し, Ho は 減少の傾向を示している ${ }^{30)}$ 。さらに同一の原炭では菏 酷な条件下で調製されたアスファルテン程, $\mathrm{H} \alpha$ の含 量は少ない48)。

\section{5 アスファルテンの化学構造}

各種結合形態水素含有率と元 素 分析值とを用いて 劳香族環構造に関する構造指数を求めることができ

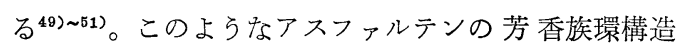
が炭種, 反応温度, 反応圧力および反応時間などの反 応条件によりどのように変化するかを明らかにするた めの研究が多くなされてきているが52 〜59), 図17 は芳香族環構造に関する構造指数と原炭の炭素含量と の関係を示した。ここで, fa. $\sigma$ 括よび $\mathrm{Hau} / \mathrm{Ca}$ は Brown/Ladner ${ }^{49)}$ とより導かれたものである。faは芳 香族性であり, 全炭素に対する芳香族炭素の割合を示 している。のは芳香族環の置換度で, 芳香族環の置換 可能な位置総数に対する実際に置換している位置数の 比である。 $\mathrm{Hau} / \mathrm{Ca}$ は芳香族環縮合度で, 芳香族環の 水素数之水素置換可能な位置数の総和 $\mathrm{Hau}$ と芳香族 炭素数 $\mathrm{Ca}$ との比である。 $\mathrm{Hau} / \mathrm{Ca}$ の実測值と種々の 多環芳香族純物質の計算値とを比較することによって 平均の芳香族環数を推定することができる ${ }^{51)}$ 。 $\mathrm{Ho} / \mathrm{H} \alpha$ は, 石油留分飞ついて Williams ${ }^{50)}$, 石炭ピリジン抽 出物について武谷ら ${ }^{611}$ が設定したものであり, 脂肪族 側鎖の平均の長さ, 言い換兄ると脂肪族側鎖の平均炭 素個数を示し, $\mathrm{Ho} / \mathrm{H} \alpha$ に 1 を加光た值が実際の炭素 個数となる。

図 $17^{300}$ 亿示したアスファルテンのこれらの構造指数 は炭種によって異なっており, また同一試料炭から生 成したものであっても生成条件によって值が変化して いる。faは低炭素含量の宗谷炭から調製したアスファ ルテンが低い值を示しているが, 宗谷炭以外の試料炭 

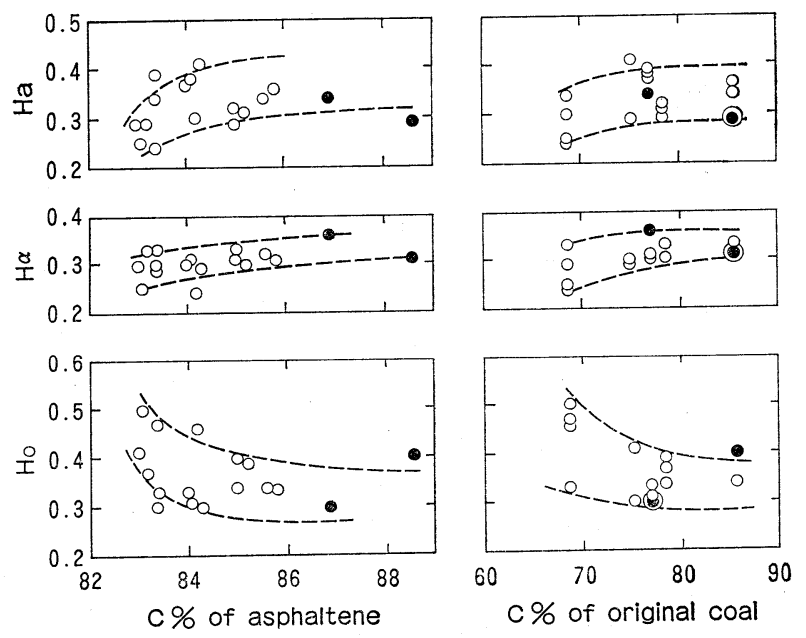

図 16 北海道炭およびアスファルテンの炭素含量とアスファルテンの各種水素含有率との関係 ${ }^{30)}$
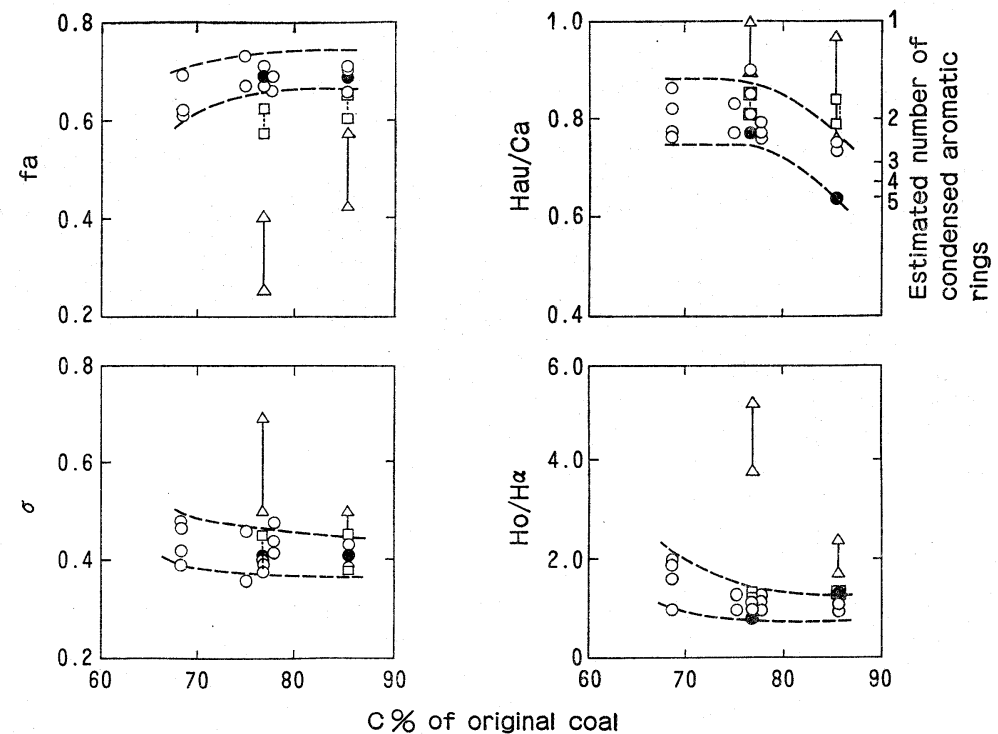

$\mathrm{C} \%$ of original coal

$$
\bigcirc\}=\text { asphaltene } \quad \triangle=\operatorname{Oil}\left(\mathrm{S}_{1}\right) \quad \square=\operatorname{Oil}\left(\mathrm{S}_{2}\right)
$$

図 17 北海道炭の炭素含量とアスファルテンの各種構造指数との関係 ${ }^{30}$

から調製されたアスファルテンは試料炭による相違は 少なくほぼ同程度の值を示している ${ }^{30)}$ 。同一の試料炭 から調製したアスファルテンでは, 苛酷な条件下で調 製したもの程 fa は高い(8)。Sklenar ら ${ }^{60)}$ とより ${ }^{13} \mathrm{C}-$ FT-NMR によるアスファルテンの fa 測定の精度に ついても検討がなされている。 $\sigma$ 抢よび $\mathrm{Ho} / \mathrm{H} \alpha$ （図 17）は原炭の炭素含量の増加とともに減少の傾向を示 して扮り, 比較的高炭素含量の原炭から調製したアス ファルテンが低炭素含量の原炭から調製したアスファ ルテンに比べて脂肪族側鎖置換基の数が少なく，また
その長さも短いことを示している。

$\mathrm{Hau} / \mathrm{Ca}$ (図17) は原炭の炭素含量の増加とともに 0.90 から 0.64 程度まで減少し, これは芳香族縮合環の 平均環数が増加する傾向を有することを示して拉り， 宗谷炭, 羽幌炭, 太平洋炭抢よび幌内炭から調製した アスファルテンでは, その芳香族縮合環の大きさは 2〜3環, 大夕張炭アスファルテンでは3〜5環である。 Pittsburgh Energy Technology Center の PDU で Kentucky coal から得られた石炭液化生成物より分 離されたアスファルテンの $\mathrm{Hau} / \mathrm{Ca}$ も0.61，0.72お 
表12 石炭液化油フラクションの水素分布および構造指数 ${ }^{61)}$

Area percent PMR spectra

\begin{tabular}{|c|c|c|c|c|c|c|c|}
\hline \multirow[b]{2}{*}{ Source } & \multirow[b]{2}{*}{ Fraction } & & \multirow[b]{2}{*}{$\sigma$} & \multirow[b]{2}{*}{$\mathrm{Hau} / \mathrm{ca}$} \\
\hline & & $\frac{\text { aromatic }}{\mathrm{Ha}}$ & $\frac{\text { benzylic* }}{\mathrm{H}_{\alpha}}$ & $\frac{\text { aliphatic* }}{\mathrm{H}_{\circ}}$ & $f_{a}$ & & \\
\hline \multirow[t]{2}{*}{ FB53-1 } & $A^{a)}$ & 38.8 & 30.3 & 30.9 & 0.75 & 0.32 & 0.61 \\
\hline & $\mathrm{HO}^{\mathrm{d})}$ & 23.7 & 31.1 & 45.2 & 0.55 & 0.41 & 0.87 \\
\hline \multirow[t]{2}{*}{ FB $57-42$} & A & 36.5 & 33.5 & 30.0 & 0.72 & 0.36 & 0.72 \\
\hline & $\mathrm{HO}$ & 25.8 & 32.9 & 41.3 & 0.56 & 0.42 & 0.93 \\
\hline \multirow[t]{4}{*}{ FB53-59 } & A & 32.6 & 34.5 & 32.9 & 0.70 & 0.4 & 0.70 \\
\hline & $A A^{b)}$ & 25.6 & 22.9 & 51.6 & 0.62 & 0.39 & 0.70 \\
\hline & $B A^{(c)}$ & 32.9 & 32.4 & 34.7 & 0.69 & 0.38 & 0.71 \\
\hline & $\mathrm{HO}$ & 23.8 & 31.9 & 44.3 & 0.54 & 0.43 & 0.93 \\
\hline
\end{tabular}

* Separation point between $\mathrm{H}_{\alpha}$ and $\mathrm{H}_{0}$ chosen at $1.94 \mathrm{ppm}$ from TMS.
a) $A=$ asphaltene
b) $\dot{A A}=$ acid/neutral fraction of asphaltene
c) $\mathrm{BA}=$ base fraction of asphaltene
d) $\mathrm{HO}=$ heavy oil

表 13 石炭液化油中の $\mathrm{CNH} 2 \mathrm{~N}+\mathrm{Z}$ タイプ芳香族炭化水素類 ${ }^{62}$

\begin{tabular}{|c|c|c|c|c|c|c|c|c|c|}
\hline \multirow[b]{3}{*}{$-z$} & \multicolumn{3}{|c|}{ Oils $^{a}$} & \multicolumn{3}{|c|}{ Asphaltenes $^{a}$} & \multicolumn{3}{|c|}{ Asphaltenes $^{\mathrm{b}}$} \\
\hline & \multirow{2}{*}{$\begin{array}{l}\text { wt. \% } \\
\times 10^{1} \\
\end{array}$} & \multicolumn{2}{|c|}{ Range In } & \multirow{2}{*}{$\begin{array}{l}\text { wt. \% } \\
\times 10^{1} \\
\end{array}$} & \multicolumn{2}{|c|}{ Range In } & \multirow{2}{*}{$\begin{array}{l}\text { wt. \% } \\
\times 10^{1} \\
\end{array}$} & \multicolumn{2}{|c|}{ Range In } \\
\hline & & $\underline{N}$ & $\mathrm{MW}$ & & $N$ & $\mathrm{MW}$ & & $\underline{N}$ & MW \\
\hline 6 & 7.5 & $9-29$ & $120-400$ & 3.6 & $7-31$ & $92-428$ & 4.1 & $7-35$ & $92-484$ \\
\hline 8 & 10.1 & $10-29$ & $132-398$ & 4.8 & $9-37$ & $118-510$ & 7.6 & $9-41$ & $118-566$ \\
\hline 10 & 8.8 & $9-30$ & $116-410$ & 5.6 & $9-40$ & $116-550$ & 6.7 & $9-40$ & $116-550$ \\
\hline 12 & 20.3 & $10-30$ & $128-408$ & 10.9 & $10-40$ & $128-548$ & 12.2 & $10-43$ & $128-590$ \\
\hline 14 & 13.8 & $12-30$ & $154-406$ & 9.7 & $12-40$ & $154-546$ & 9.8 & $12-41$ & $154-560$ \\
\hline 16 & 10.6 & $12-30$ & $152-404$ & 9.8 & $12-40$ & $152-544$ & 11.0 & $12-41$ & $152-558$ \\
\hline 18 & 11.6 & $14-30$ & $178-402$ & 12.2 & $14-40$ & $178-542$ & 12.6 & $14-41$ & $178-556$ \\
\hline 20 & $4: 1$ & $15-30$ & $190-400$ & 8.6 & $15-40$ & $190-540$ & 8.8 & $15-44$ & $190-596$ \\
\hline 22 & 4.6 & $16-30$ & $202-398$ & 12.0 & $16-41$ & $202-552$ & 12.5 & $16-40$ & $202-538$ \\
\hline 24 & 1.9 & $18-31$ & $228-410$ & 8.4 & $18-41$ & $228-550$ & 7.6 & $18-42$ & $228-564$ \\
\hline 26 & 1.4 & $18-31$ & $226-408$ & 9.5 & $18-41$ & $226-548$ & 9.1 & $19-42$ & $240-562$ \\
\hline 28 & & & & 5.2 & $20-39$ & $252-518$ & 4.0 & $20-42$ & $252-560$ \\
\hline 30 & & & & 6.9 & $22-40$ & $278-530$ & 9.4 & $22-42$ & $278-558$ \\
\hline 32 & & & & 3.0 & $22-39$ & $276-514$ & 1.8 & $23-43$ & $290-570$ \\
\hline 34 & & & & 3.5 & $22-41$ & $274-540$ & 0.5 & $24-40$ & $302-526$ \\
\hline 36 & & & & 1.5 & $24-41$ & $300-538$ & 0.3 & $24-43$ & $300-566$ \\
\hline 38 & & & & & & & 0.3 & $26-41$ & $326-536$ \\
\hline 40 & & & & & & & 0.2 & $28-39$ & $352-508$ \\
\hline 42 & & & & & & & 0.04 & $29-39$ & $364-506$ \\
\hline Total & 94.6 & & & 115.1 & & & 118.5 & & \\
\hline
\end{tabular}

a. Data from osu analysis.

b. Data from Exxon analysis.

よび0.70といら值を示し，その芳香族縮合環数が 3〜

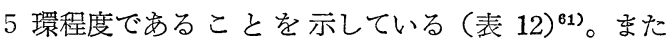
COED プロセスにより Colorado Bear Mine coalか ら得られた石炭液化生成物から分離されたオイル特よ びアスファルテンの FI 影よび EI マススペクトロメ トリーによる分析結果は，いずれのフラクションもー $6 Z$ から $-26 Z$ の芳香族孷 化水素考多く含んでいる ことを示して和り，このことは 1 環から 4 環程度の芳
香族炭化水素を含有していることを示している（表

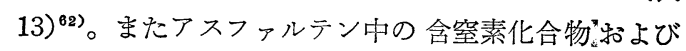
含酸素化合物の芳香族環構造に関する検討がマススペ クトロメトリーを用いてなされている3441)。Schweighardt ら ${ }^{41}$ は, アスファルテン中の含窒素化合物の 崖素数分布および構造タイプを明らかにした(表14)。 その結果, 含窒素化合物の芳香族環数は 1 環 (ピリジ ン類）から 6 環 (アザジベンゾピレン類) 程度である 
表 14 アスファルテン中の含窒素化合物 ${ }^{41)}$

Asph Asph A Asph B

\begin{tabular}{lccc}
$z \mu$ & & \multicolumn{3}{c}{ Carbon Number Range } \\
\cline { 3 - 4 }-5 & $5-7$ & $6,8,9$ & 6 \\
-7 & $8-11$ & $9-12$ & $8-12$ \\
-9 & $8-14$ & $9-15$ & $8-14$ \\
-11 & $9-14$ & $9-15$ & $9-14$ \\
-13 & $11-16$ & $11,12,14-17$ & $11-16$ \\
-15 & $11-19$ & $11,12,14-19$ & $11-17$ \\
-17 & $13-20$ & $14-20$ & $13-18$ \\
-19 & $14-20$ & $14-21$ & $14-19$ \\
-21 & $15-21$ & $15-22$ & $15-20$ \\
-23 & $17-21$ & $18-23$ & $17-21$ \\
-25 & $17-21$ & $19-22$ & $17-21$ \\
-27 & $19-23$ & $20-23$ & $19-22$ \\
-29 & $21-23$ & $21-23$ & 21 \\
-31 & $21-23$ & 21,22 & 21,22 \\
-33 & 23,24 & &
\end{tabular}

\section{Possible Structural Types}

Pyridines

Azaindans

Dihydroquinolines; Indoles

Quinolines

Phenylpyridines

Azafluorenes; Carbazoles

Acridines

Azabenzo[ghi] fluorenes

Azapyrenes; Benzocarbazoles

Benzacridines

Azabenzo[ghi] fluoranthenes

Azabenzopyrenes; Dibenzocarbazoles

Dibenzacridines

Azabenzoperylenes

Azadibenzopyrenes

Formulas derived by HRMS represent isomers and fragment ions as well as molecular ions.

ことが明らかとなっている ${ }^{41)}$ 。アスファルテンの塩基 性フラクション(BA)では，ピリジン環执よびアニリ ン環を有する縮合芳香族環の大きさは1〜環の範囲， また酸性/中性フラクション (AA) では, ピロール環 は1〜5環の芳香族環と結合している。一方, AA中に 存在するフェノール構造を有する縮合芳香族環の大き さは 4 環以下である ${ }^{34)}$ こ林らアスファルテンの縮 合芳香族環の大きさに関する知見は 1 環から 6 環程度 までの分布の存在を示しているが，平均的には 2 環か ら 5 環程度の縮合芳香族環教造をアスファルテンは有 するものと考觉ることができる。

以上の結果は，原炭の種類や反応条件によってかな り広い範围の化学構造を有するアスファルテンを生成 しうることを示している。4.2では元素組成の变化か ら，元素組成の異なる原孷から調製したアスファルテ ンが比較的類似した元素組成を有することを述べた。 しかしながら、フスファルテンの芳香族環構造に関す る構造指数が原岸の炭素含量と相関関係を有するとこ ろから，芳杳族環構造あるいは構造単位学るいはマイ クロ構造といったレベルからみるとアスファルテンは 各原炭に固有の化学構造特性を受汗継いでいるるのと 考光られる。

\section{6 アスファルテンの高次構造}

次に，4.5 で述べた䂋造単位あるいはマイク口構造 といったレベルからさらに分子構造あるいは高次構造 といったレベルでアスファルテンの化学構造を考察し
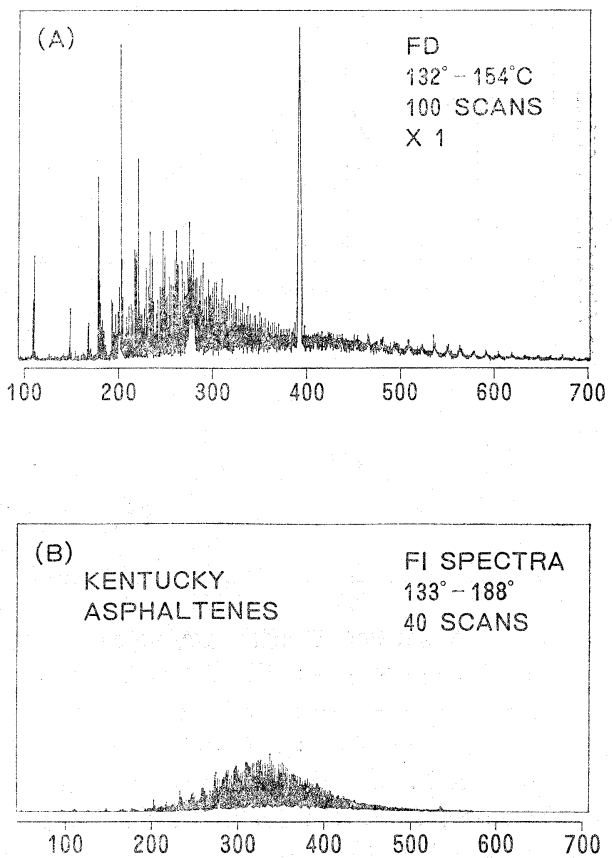

(A) $\mathrm{FD}$ マススペクトル

(B) FI マススペクトル

図18 Kentucky SRC アスファルテンのマスス ペクトル ${ }^{64)}$

てみたいと思う。

図1864 は FD 打よび FI マススペクトロメトリー

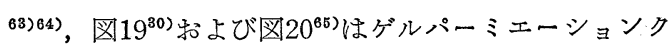




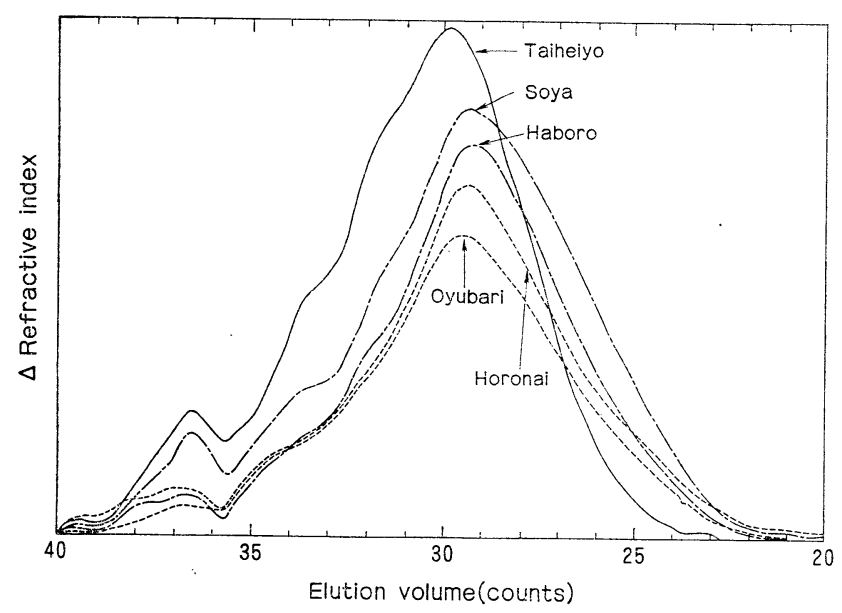

図 19 北海道炭アスファルテンの GPC クロマトグラム ${ }^{30}$

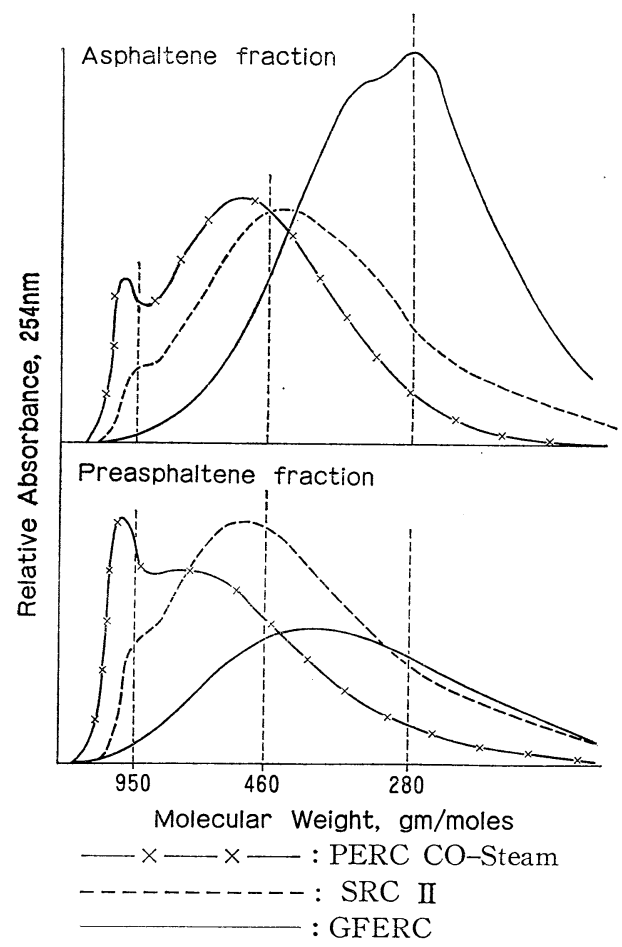

(PERC : Pittsburgh Energy Research Center, GFERC : Grand Forks Energy Research Center)

図20 種々のプロセスから得られたアスファルテ ンおよびプレアスファル テンの分子量分 布 ${ }^{65}$ )

ロマトグラフィー（GPC）により分子量分布を測定 したものであるが，分子量の連続的な分布を示唆して いる。図1930)の溶出曲線のピーク頂点位置は, 表 $15^{30}$ に示した平均分子量が大きい程低カウント側にあり,
平均分子量とピーク頂点位置は相関関係を有してい る。表15和よび図 2130) に示した平均分子量の実際の 中味は, 図19の GPC 曲線で示されるように分子量分 布を有しているわけであるが，一般的には原炭の炭素 含量の増加とともにアスファルテンの平均分子量は増 加する。しかしながら, 太平洋炭アスファルテンはこ れらの傾向とは異なり小さな分子量を有している。表 15 中の $\mathrm{M}_{\mathrm{N}}$ は 4.5 で述べた構造指数を用いて算出し た平均構造単位の質量であり，実測した平均分子量 $\left(M_{V}\right)$ との比 $M_{V} / M_{N}$ は平均的な重合度を示するの と考えられる。これらの結果は, アスファルテンでは 2 3 量体の分子構造, オイルでは単量体より分子構造 が構成されていることを示唆している。

図2266(67) Synthoil プロセスからのアスファルテ ンの分子量測定結果であるが, ベンゼン, クロロホル ムおよびテトラヒドロフラン溶媒中でいずれもアスフ ァルテン濃度の高い領域においては, アスファルテン の会合が起っていることを示している。また会合の程 度は非極性溶媒において著しいが，希釈溶液では三者 とも一致した分子量を与えている。このような会合が 存在する事実は粘度の測定結果(図23) ${ }^{61}$ においても認 められている。つまり，アスファルテンの濃度ととも に粘度が増加している。会合のタイプとしては次の 3 つが考允れる(図24) ${ }^{68)}$ :
i ) $\pi-\pi$ 会合 ${ }^{67)}$
ii）水素結合 28 (61)69; 74)
iii ）酸一塩基塩形成 26)27)48)75) 78) アスファルテンの酸一塩基構造は, Sternberg $ら^{75)}$ よって見い出された。酸性フラクション（A A ）就よ び塩基性フラクション（BA）は，アスファルテンを 
表 15 北海道炭高压水素化分解生成物の平均分子量 (MV), 平均構造単位質量 (MN) および平均重合 度 $(\mathrm{MV} / \mathrm{MN})^{30}$

Sample

Soya coal asphaltene

Haboro coal asphaltene

Taineiyo coal asphaltene

Horonai coal asphaltene

Oyubari coal asphaltene

$\overbrace{\text { Temp. ('C) Time(min.) }}^{\text {Reaction condition }}$

400

400

400

400

400
$M v^{*}$

550

690

470

$420^{* *}$

710.

830

$490 * *$
$\mathrm{Mn}^{* * *} \quad \mathrm{Mv} / \mathrm{Mn}$

270

$240^{\circ}$

2.9

2.9

$220 \quad 3.2$

$260 \quad 3.2$

$\begin{array}{rcccccc}\text { Taiheiyo coal Oil }\left(S_{1}\right) & 350-400 & 5-7 & 220-260 & 270-350 & 0.7-1.0 \\ & \text { Oil }\left(S_{2}\right) & 400 & 10-120 & 220-260 & 190-220 & 1.0-1.3 \\ \text { Oyubari coal Oil }\left(S_{1}\right) & 350-400 & 4-29 & 280-300 & 260-280 & 1.0-1.1 \\ \text { Oil }\left(S_{2}\right) & 400 & 10-123 & 260-280 & 190-230 & 1.2-1.5\end{array}$

${ }^{*} \mathrm{Mv}$ :molecular weight determined by vapor pressure osmometry of products hydrogenated in a $500 \mathrm{cc}$ shaking-type autoclave

**Mv:molecular weight determined by vapor pressure osmometry of products hydrogenated in a 12 liter rotating-type autoclave

${ }^{* * *} \mathrm{Mn}$ :weight of average structural units calculated numerically from the value of structural parameter

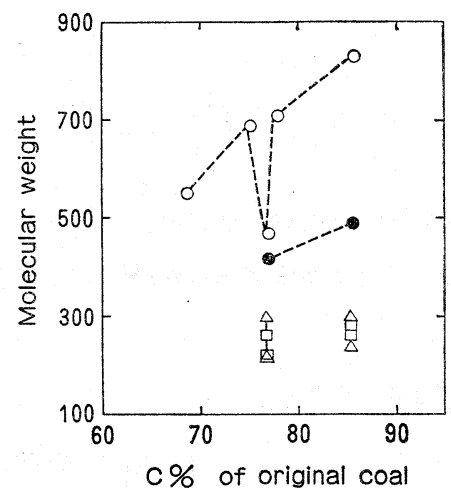

$\bigcirc=$ asphaltene $\triangle=\operatorname{Oil}\left(\mathrm{S}_{1}\right)$ $\square=\operatorname{Oil}\left(\mathrm{S}_{2}\right)$

図21 北海道炭の炭素含量と高圧水素化分解生成 物の平均分子量との関係 ${ }^{30}$

トルエン中に溶解し, その溶液に $\mathrm{HCl}$ ガスを通すこ とにより分離できる。この際, $\mathrm{BA}$ は不溶性の $\mathrm{HCl}$ ア ダクトとして沈澱し，AA は溶液中に残り，溶媒を留 去することにより回収される。そしてアスファルテン の酸一塩基構造が図 $25^{75}$ のように提案されている。A $\mathrm{A}$ 中の酸素はフェノール性水酸基として, 窒素はピロ ールタイプとして存在し，BA 中では酸素は環内ある

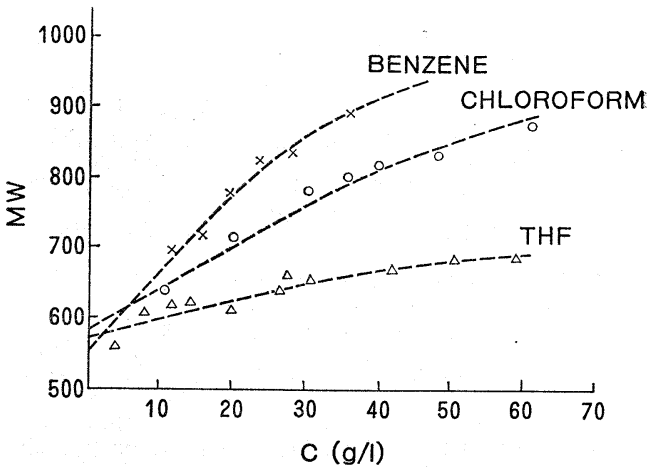

図22 種々の溶媒中での Synthoil アスファルテ ンの平均分子量 ${ }^{67}$

いはエーテルとして，窒素はピリジンのように環内に 存在する。そして図25に示したよらな酸一塩基構造は, 酸性のフェノール性水酸基と塩基性窒素グループとの 水素結合によって形成される ESR 強度の温度依存性（図 26）からアスファルテン 中の AA とBA との間の結合力について検討してい るが, charge transfer interaction ${ }^{80)}$,つまり $\pi-\pi$ 会 合は比較的重要ではなく，水素結合が支配的であると 考兄られる。同様に分子量測定の結果 ${ }^{66)}$ からも石油系 アスファルテンに対して提案されている charge tra- 


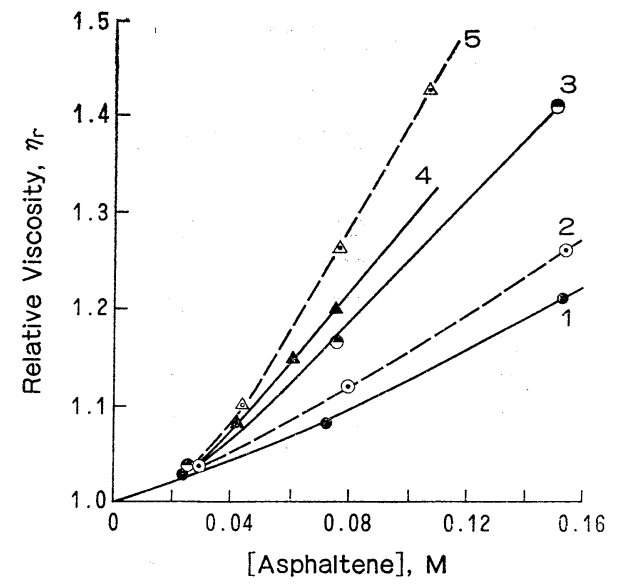

試料：FB57-42

1. ベンゼン中の酸性フラクション $(\mathrm{AA})$

2. (重質油+ベンゼン)中の酸性フラクシ ョン (AA)

4. ベンゼン中の塩基性フラクション(BA)

5. (重質油十ベンゼン)中の塩基性フラク ション (BA)

試料 : FB 53-59

3. ベンゼン中の酸性フラクション (AA)

図23 アスファルテンの添加量による相対粘度の変化 $(293 \mathrm{~K})^{61)}$

i) $\pi \sim \pi$ association

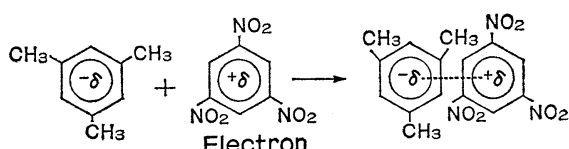

Electron rich Electron $\quad$ Complex

ii) Hydrogen-bonding<smiles>CCOC(=O)C1C=CC(=O)C=C1</smiles>

Quinone Hydroquinone Hydrogen bonding

iii) Acid-Base salt formation

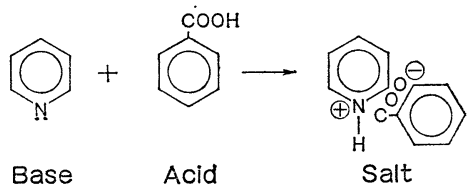

図24 分子会合のタイプ ${ }^{\circ 8)}$

nsfer complexation よりも石炭系アスファルテンに ついては水素結合モデルの方が妥当であるうと考兄ら れる。さらに Sternberg らの結果によれば, BA は 黒く, ペンタンに不溶で, 光, 空気および熱に対して敏 感で，比較的高温でる固体であるが，A Aは樹脂質の 琥珀色の物質で, ペンタンに少なくとも50\%可溶で,

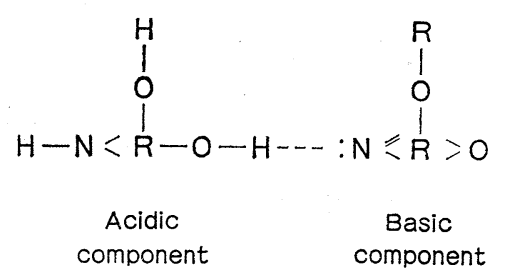

アスファルテンの酸性および塩基性成分 ${ }^{75)}$

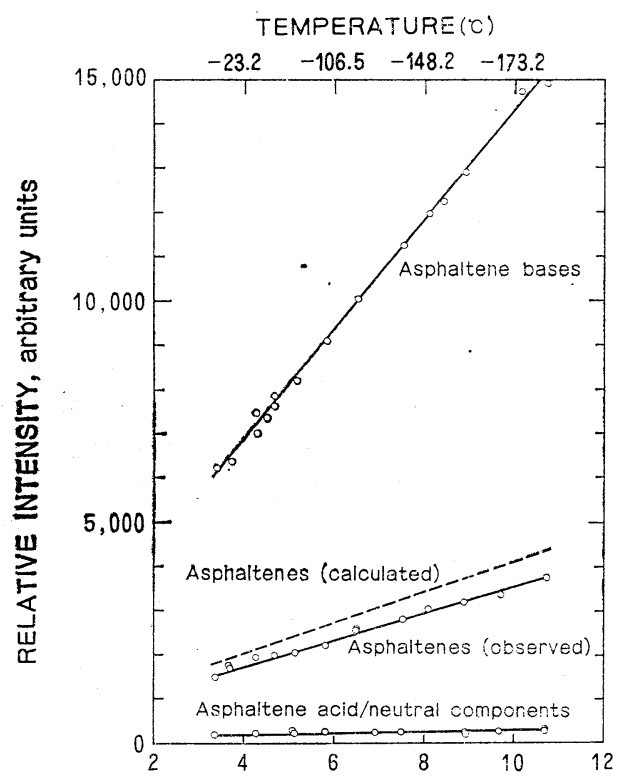

RECIPROCAL TEMPERATURE $\times 10^{-3}$ deg $\mathrm{K}^{-1}$ 図26 アスファルテンのESR強度の温度依存性 ${ }^{79}$

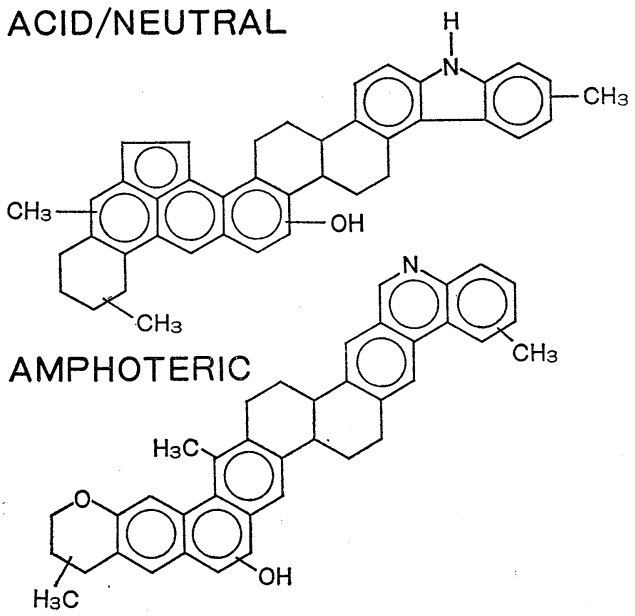

図27 Synthoil アスファルテンの化学構造モデル ${ }^{67)}$ 


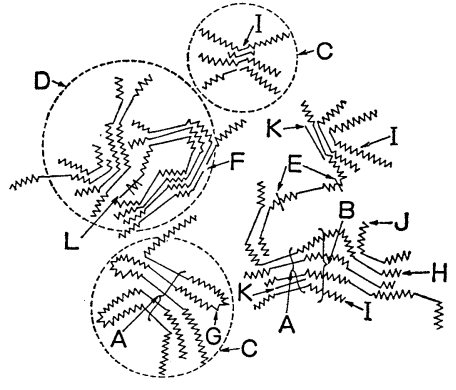

Macrostructure of Asphaltics
A. Crystallite
B. Chain Bundle
C. Particle
D. Micelle
E. Weak Link
F. Gap and Hole
G. Intracluster
H.Intercluster
I. Resin
J.Single Layer
K.Petroporphyrin L. Metal

図28 アスファルテンのマクロ構造 ${ }^{67)}$

光, 空気および熱に齐して抵抗性があり, $50 \sim 100^{\circ} \mathrm{C}$ で液状である ${ }^{26)}$ 。したがって， BA は AA よりも大 部分は大きな分子から構成されている48)。

一方, Yen ${ }^{67}$ は石炭系アスファルテンのマイクロ構 造およびマク口構造として図27特よび図28のようなモ デルを提案している。X線データから求めた図28中の 積層構造は3〜4層であり, 石油系アスファルテンに比 ベて少ないが，これは芳香族環構造が小さなためであ ろう。

\section{文献}

25) H.W. Sternberg, R. Raymond, S. Akhtar, ACS Div. Petroleum Chem., Preprints, 20, (2), 541 (1975)

26) H.W. Sternberg, R. Raymond, F. K. Schweighardt, ACS Div. Petroleum Chem., Preprints, 21 (1), 198 (1976)

27) B. D. Bockrath, R. B. La Count, R. P. Noceti, Fuel Processing Technology, 1, 217(1977/1978)

28) K. C. Tewari, N. Kan, D. M. Susco. N. C. Li, Anal. Chem., 51, 182 (1979)

29) D. Finseth, M. Hough, J. A. Queiser, H. L. Retcofsky, ACS Div. Petroleum Chem., Preprints, 24 (4), 979 (1979)

30) 吉田諒一, 前河涌典, 武谷 愿, 燃協誌, 53 , 1011 (1974)

31）武谷 愿, 伊藤光臣, 牧野和夫, 横山 晋, 北海 道大学工学部研究報告, no. 35, p. 113 (1964)

32) R. J. Baltisberger, K. J. Klabunde, V.I. Sterberg, N. F. Woolsey, K. Saito, W.
Sukalski, ACS Symp. Series no. 71, p. 294 (1978)

33）上田 成, 長谷川義久, 前河涌典, 横山慎一, 矢 部勝昌, 吉田雄次, 佐藤俊夫, 燃協誌, 50, 930 (1971)

34) D. Bodzek, T. Krzyzanowska, A. Marzec, Fuel, 58, 196 (1979)

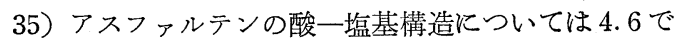
詳述する $(\text { 図25 })^{76)}$

36）吉田諒一, 前河涌典, 横山 晋, 武谷 愿, 燃協 誌, 54, 332 (1975)

37) F. R. Brown, S. Friedman, L. E. Makousky, F. K. Schweighardt, Appl. Spectrosc., 31, 241 (1977)

38) I. Schwager, T.F. Yen, Anal. Chem., 51, 569 (1979)

39) S. Friedman, M. L. Kaufman, W.A.Steiner, I. Wender, Fuel, 40, 33 (1961)

40）長谷川義久, 上田成, 横山慎一, 吉田雄次, 前河 涌典, 燃協誌, 53, 995 (1974)

41) F. K. Schweighardt, C. M. White, S. Friedman, J. L. Shultz, ACS Div. Fuel Chem., Preprints, 22 (5), 124 (1977); ACS Symp. Series No.71, p. 240 (1978)

42) F. K. Schweighardt, H. L. Retcofsky, S. Friedman, M. Hough, Anal. Chem., 50, 368 (1978)

43) R. Husack, C. Golumbic, J. Am. Chem. Soc., 73, 1567 (1951)

44) 吉田諒一, 学位論文, :p. 160 (1973)

45) R. G. Ruberto, D. C. Cronauer, ACS Symp. Series no. 71 , p. 50 (1978)

46) J. K. Brown, J. Chem. Soc.,744 (1955)

47) W. Francis, "Coal", Second Edition, E. Arnold, London, 1961, p. 724

48) B. C. Bockrath, C. L. Delle Donne, F. K. Schweighardt, Fuel, 57, 4 (1978)

49) J. K. Brown, W. R. Ladner, Fuel, 39,87 (1960)

50) R.B. Williams, Symposium on Composition of Petroleum Oils. ASTM Spesial Technical Publication no. 224 (1957)

51）武谷 愿, 伊藤光臣, 鈴木 章, 横山 晋, 燃協 誌, 43, 837 (1964)

52）前河涌典, 下川勝義, 石井忠雄, 武谷 愿, 燃協 
誌, 46, 927 (1967)

53）前河涌典, 石井忠雄, 武谷 愿, 燃協誌, 51 , 1233 (1972)

54）前河涌典, 上田 成, 横山慎一, 長谷川義久, 中 田善徳, 吉田雄次, 燃協誌, 53, 987 (1974)

55）前河涌典, 上田 成, 石井忠雄, 武谷愿, 燃協誌, 56, 329 (1977)

56）横山慎一, 奥谷 猛, 上田 成, 中田善徳, 吉田 忠, 吉田諒一, 前河涌典, 長谷川義久, 吉田雄次 燃協誌, 57, 182 (1978)

57）前河涌典, 吉田諒一, 石井忠雄, 武谷 愿, 燃協 誌, 59, 732 (1980)

58）長谷川義久, 前河涌典, 日化, $\mathbf{1 9 8 0}, 916$

59) K. Ouchi, T. Chikada, H. Itoh, Fuel, 58, 37 (1979)

60) V. Sklenář, M. Hájek, G. Sebor, I. Lang, M. Suchánek, Z. Starcuk, Anal. Chem., 52, 1794 (1980)

61) K. C. Tewari, N. C. Li, ACS Div. Petroleum Chem., Preprints, 24 (4), 982 (1974)

62) S. E. Scheppele, P. A. Benson, G. J. Greenwood, Q. Grindstaff, ACS Div. Petroleum Chem., Preprints, 24 (4), 963 (1979)

63) M. Anbar. G. A. St. John, Fuel, 57, 105 (1978)

64) G. A. St. John, S. E.Buttrill, Jr., M. Anbar, ACS Symp. Series no. 71, 223 (1978)

65) C. L. Knudson, J.E. Schiller, A. L. Rund, ACS Symp. Series no. 71, p. 301 (1978)

66) I. Schwager, W. C. Lee, T.F. Yen, Anal. Chem., 49, 2363 (1977)

67) T.F. Yen, ACS Div. Petroleum Chem.,
Preprints, 24 (4), 901 (1979)

68) T.F. Yen, The 1976 Coal Chemistry Workshop, Preprints, SRI, Menlo Park, p. 144 (1976)

69) F. K. Schweighardt, R. A. Friedel, H. L. Retcofsky, Appl. Spectrosc., 30, 291 (1976)

70) S. R. Taylor, L. G. Galya, B. J. Brown, N. C. Li, Spectrosc. Letters, 9 (11), 733 (1976)

71) S. R. Taylor, N.C. Li, Fuel, 57, 117 (1978)

72) K. C. Tewari, L. G. Galya, K. M. Egan, N. C. Li, Fuel, 57, 245 (1978)

73) K. C. Tewari, K. M. Egan, N.C. Li, Fuel, 57, 712 (1978)

74) K. C.Tewari, J-T. Wang, N. C. Li, H. J. C. Yeh, Fuel, 58, 371 (1979)

75) H. W. Sternberg, R. Raymond, F. K. Schweighardt, Science, 188 (no. 4183), 49 (1975)

76) H.W. Sternberg, ACS Div. Fuel Chem., Preprints, 21 (7), 1 (1976)

77) F. K. Schweighardt, H. L. Retcofsky, R. Raymond, ACS Div. Fuel Chem., Preprints, 21 (7), 27 (1976)

78) P.A. S. Smith, J. C. Romine, S. P. Chon, ACS Div. Petroleum Chem., Preprints, 24 (4), 974 (1979)

79) H. L. Retcofsky, G. P. Thompson, M. Hough, R. A. Friedel, ACS Symp. Series no. 71, p. 142 (1978)

80) I. Schwager, J. T.-Kwan, J. G. Miller, T.F. Yen, ACS Div. Fuel Chem., Preprints, 23 (1), 284 (1978) 


\title{
Chemistry of Coal-Derived Asphaltenes (II)
}

\author{
Ryoichi YosHIDA
}

(Government Industrial Development Laboratory, Hokkaido)

SYNOPSIS : - Asphaltene is an intermediate product in coal hydroliquefaction. The properties of asphaltene exert a considerable influence on the various aspects of the primary coal hydroliquefaction products and on the reactivity of the primary product in further processing. In Part I the definition of asphaltene and methods for its separation were reviewed. In Part II the chemical structure of asphaltenes derived from various coals are reviewed from the results of ultimate analysis, infrared spectroscopy, nuclear magnetic resonance spectroscopy, vapor pressure osmometry, gel permeation chromatography and mass spectroscopy. In the final part, the reactivity of asphaltene will be reviewed. 